\title{
Integration of HE system of Azerbaijan in the Global World
}

\author{
Abbasova, Ulviyya ${ }^{a}$ and Babayeva, Natavan ${ }^{b}$ \\ ${ }^{a}$ Department of International Relations, Baku Slavic University, Azerbaijan; ${ }^{b}$ Deparment \\ of English Philology, Baku Slavic University, Azerbaijan.
}

\begin{abstract}
This article deals with the analysis of some important reforms and innovations implemented in the education sector by the government in Azerbaijan. After gaining the independence Azerbaijan started successfully to move forward towards the development as an independent country. The country established the close relations with different international organizations and institutions. After Azerbaijan signed on to the Bologna process, the Ministry of Education developed a comprehensive action plan, calling for the modernizing of the higher education system, a transfer to the credit system, the elaboration of new diploma and the recognition of international documents on higher education. As a result, the government of Azerbaijan started the implementation processes of reforms focused on the improvement of the quality of education in order to integrate to international standards. The Ministry of Education of Azerbaijan closely collaborates with major international organizations such as: The Council of Europe, UNESCO, World Bank, UNICEF, ISESCO, EU and so on. Cooperation between Azerbaijan and the EU is carried out within the framework of TEMPUS/TACIS, Erasmus+, Twinning/TAIEX programs. This article provides a brief overview about the above mentioned programs, their application processes, as well as the results and their influences in education system of Azerbaijan .
\end{abstract}

Keywords: reforms, education system, integration ,international relations, Bologna process, standard 


\section{Introduction}

In a current world of globalization, education like any other spheres of political, economic and social life with an easier access to universities, the education systems now are expected to provide better quality and meet the demands put forward by external environment, generally reforms and innovations undertaken to improve the quality of education is a thorough process based on multiple and comprehensive approaches to elementary, secondary as well as higher education system.

There is a high attention to the development of education in order to secure the country's future sustainable development. In this regard the legislative frameworks to recognize the system of education, as well as reforms in international context, are continuing processes of improvements and innovations.

After Azerbaijan gained its independence, the need for fundamental reforms in education as in other areas emerged. The start of transition process from the Soviet education system to modern and international standards education system goes back to the md-90s of the last century. The modern education system of Azerbaijan consists of three historical periods: the first period being from 1918 to 1920, the next period from 1920 to 1990 imposed by the Soviet Union, and the current education system which has been maintained since the country becameindependent from the Soviet in 1991.

In 1993, the higher education system became a two-tier higher education system consisting of undergraduate education and post-graduate education. Since then, significant reforms have been carried out in the higher education system, as the existing regulations were improved and a credit system was adopted by the higher education institutions. After the first Bachelor degree alumni graduated in 1997, a total of 32 higher education institutions (both public and private) started providing post-graduate education in the second tier of higher education (www.edu.gov.az).

Azerbaijan's education is open to global reforms. The process of reforms leads to quality transformation.

The involvement of the students in the decision - making process became average for promoting quality counted overall. Student's opinion was considered in curriculum design, students are able to select or reject a course and students' assessment becomes an important part in course and teacher evaluation. 


\section{Methods}

In 2005 Azerbaijan joined the process made a need to get higher education in the country, meeting the Common European Standards. Since 2005 reforms are carried out in this direction. One of the most important steps in higher education reform is the adoption of the state program approved by the president. The purpose of this program was the integration of higher education in Azerbaijan to European education space. (www.euroeducation.net, The Eurapion Education Directory)

Recognizing diplomas' grades in Europe and in other countries is one of the achievements in the education system of Azerbaijan.

Development of education in Azerbaijan, providing of children and young people with world class education, training of highly qualified personnel comprise of important part of the strategy of the country's president on turning of oil capital intellect to development of professionalism. Nowadays more than 5000 students are studying abroad in different universities. Azerbaijani youth sent for study abroad in the expense of state on all levels of education for bachelor's, master's, residency, doctoral degrees as well as qualification improvement and retraining exchange of students among higher education institutions.

They are sent for education to developed countries like Australia, South Korea, China, Malaysia, Singapore, the US, Germany, France, the Netherlands, Norway, Sweden, Finland, Italy, Belgium and Great Britain. (xaricdetehsil.edu.gov.az.-State Scholarship Program)

The country joined the Bologna system in 2008. One of the main requirements of the Bologna system is the organization of educational process in accordance with the European credit transfer system.

Joining the Bologna process has a special role in the reforms in higher education. After launching Bologna system the universities approached this process individually.

The introduction of the "Bologna process" in the education system Azerbaijan creates conditions for academic recognition of educational programs inside and outside the country. The system also allows students to continue their education at other universities and increase their competitiveness on a labor market.

The principle goal of the system of higher education in Azerbaijan is to educate and train highly-skilled specialists in line with the demands of the community and labor market.

At the same time the integration of the higher education system of our country in the European space of the higher education ensuring mutual recognition diplomas and development of students and teaching mobility. At present these rules are of great 
importance as the adjusting frame document and from the point of view of integration into educational systems of the European countries.

Government covers all tuition fee expenses of the following students;

- $\quad$ Students from refugee families and children of national heroes

- $\quad$ Students who deprived of parental care

- Special talented students who get the highest points from admission examinations

- Language instruction, besides of Azerbaijani, Russian and Turkish courses are offered in English and French

Today each university has its own international relations with universities in Europe.

In 2009 Azerbaijan government adopted a new law on education after the public debate in the parliament and its implementation started. Reforms in the higher education field are implemented within the cooperation with European institutions, The European Union with European Commission. The new Law "On Education" introduced a three-cycle higher education system. Since then the higher education system of Azerbaijan is comprised of the following levels;

1) Undergraduate (with the exception of medical studies)

2) Post-graduate (with the exception of medical studies)

\section{3) Doctorate}

Undergraduate courses generally take four years (five years for part-time programs) and cover a wide range of domains. Undergraduate courses provide student with possibility of employment in certain specialized jobs after graduation. Upon completion of undergraduate courses, students are awarded the academic title "bakalavr" (Bachelor degree), within a specific field, and they can work in various fields except in scientific and pedagogical areas at scientific research institutes and higher education institutions.

Post-graduate courses typically last for 2 years (two and a half years for part-time programs), provide students with training in a certain field of study from scientific research or professional viewpoints and enable them to engage in professional activity, scientific research and pedagogical activity. Upon completion of graduate courses, students are awarded the academic title "magistr" (Master degree).

Doctoral education is the highest level of the higher system and is carried out at higher education institutions and academic departments (doktorantura) of scientific organization. Upon completion of doctoral studies students are awarded the academic title of Doctor of 
Philosophy-Ph.D. or Doctor of Science-D.Sc.(Law of the Republic of Azerbaijan "About Education"2009)

Strategy of the government is to improve HE sector.The President of the Azerbaijan Republic issued an instruction on the preparation on the Development Concept "Azerbaijan-2020 Vision of the Future" and National Strategy for the Development of Education in the Republic of Azerbaijan. (Development Concept: Azerbaijan - 2020: Outlook for the future, 2012)

As it was mentioned above Azerbaijan has accepted the Bologna Declaration and during the last decade, the Azerbaijan Republic has demonstrated impressive achievements in the education system. One of them and the main one is cooperation between EU which is carried out within the framework of Erasmus+ program. Here we can mention the PETRA project which shows its benefits by transferring the knowledge and experience established in European Universities to Azerbaijan Universities. The objective of the project is to promote teaching and learning excellence in Azerbaijan HEI's. The benefits of this project let us contribute to the improvement of the learning and teaching process within the university and across universities in Azerbaijan.

Besides, a number of TEMPUS projects were implemented in the country,initiated the modernization process at HEI's. More than $80 \%$ of the TEMPUS projects in Azerbaijan have been implemented in the field of curriculum development and university management. Currently 15 universities are already involved in TEMPUS projects in different priority areas. (www.tempus-az.org).

\section{Conclusion}

Alongside with it, nowadays it would be better to benefit of the programs which are held in our country by the Ministry of Education. As we mentioned above Azerbaijanis open to global reforms especially in education system because education is one of the structures of the government. We have our own institutional ESG system which is held by the Ministry of education of Azerbaijan or by the universities. But it is appreciated to see or observe our results from aside. We can improve this sphere sharing and exchanging ideas, views, opportunities and competences.

Saying without any doubt, we believe and hope the educational development in Azerbaijan. The Government takes all necessary steps, through improvement of quality in education, to increase the social welfare of its population and facilitate the country's progress. 


\section{References}

Azerbaijan Teachers Institute news, 2009

Development Concept:”Azerbaijan-2020;Outlook for the Future “. December29,2012

European Ministers of Education (1999). The Bologna Declaration of 19 June 1999 Joint declaration of the European Ministers of Education. Available at: http://www.ond.vlaanderen.be/hogeronderwijs/bologna/documents/MDC/BOLOGNA_ DECLARATION1.pdf Accessed on 28/01/2016

http://www.ond.viaandern.be/hogeronderwis/bologna/links/National-reports-2007// National Report Azerbaijan2007.pdf

Law of the Republic of Azerbaijan” About Education”,2009

Law on Education -http: //www.azertag.com/store/News/Decrees Orders Laws/ GANUNTAHSIL\% 20 Hagginda.htm Baku 2009

Mikailova, U. \& Radsky,V. (2013) School Leadership in Azerbaijani early childhood education: implications for education transfer. Center for Innovations for Education Azerbaijan

Ministry of Education of the Republic of Azerbaijan . Available at: http://www.edu.gov.az

National Tempus Office in Azerbaijan. Available at: http://www.tempus-az.org

Seyidov, S ( 2011) Reforms In Education International Integration :The Case of Azerbaijan

State Scholarship Program . Available at: http://xaricdetehsil.edu.gov.az

The Europian Education Directory. Available

http://www.euroeducation.net/prof/azerco.htm

The State Statistical Committee of the Republic of Azerbaijan 